\title{
Applying Systems Philosophy: Teaching Design Enhancing Healthy Living in Light of Feng-Shui
}

\author{
Ping Xu \\ University of Colorado Boulder
}

This paper integrates feng-shui research and consultant experiences with teaching design enhancing healthy living. Feng-shui is an ancient Chinese systematic model used to harmonize people with their environment, which can be utilized as a clue to develop a paradigm of healthy living. Homesites located in areas prone to natural hazards could lead to injury, illness, and fatalities. Inadequate ventilation can foster indoor pollutants, radon, bacteria, and viruses. Inappropriate spatial designs can cause physical and mental illness. This interdisciplinary approach to healthy living helps students improve living conditions and develop design skills. Finally, it enhances students' fundamental worldview of systems thinking.

Keywords: healthy living, systems philosophy, undergraduate teaching, spatial design, feng-shui

\section{INTRODUCTION}

The pandemic has increased student demand to learn more about healthy living in their homes. Boulder is an expensive college town where every square foot can be rented. This reality has put many students in undesirable living conditions because of the exorbitant rent prices and housing shortage. A house should promote healthy living with concerns for safety, physical and mental health, and wellbeing. Woefully, the concepts and knowledge of healthy living rarely appear in the curriculums of architectural education. Also, there is insufficient research on the relationship between the built environment and its impacts on human health (Rice and Drane, 2020).

Design education contains several majors, including landscape planning, urban planning, urban design, landscape design, architecture, and interior design, with isolated curriculums for each discipline. The inherent isolation among disciplines has manifested a weakness in design education. Moreover, architectural design often ignores human behaviors, emotions, health, and safety. Specifically, in architectural studios, the designer's personal interest, form preference, and ego often are the predominant drivers in creating a space. Creating spaces for serving people is the primary intention of architecture. When designers omit this intention, the design appears hollow. Ian McHarg states, "The measure of architecture is its ability to enhance human health and wellbeing" (McHarg, 1996, P. 85).

Integrating feng-shui research and consultant experiences with teaching, the author, a professor in architecture and environmental design, has taught a theory and method course on systems theory and healthy living at an undergraduate program in Colorado. This course introduces systems philosophy (by Bertalanffy and Laszlo) and discusses feng-shui as an ancient systematic model for environmental design. Feng-shui is an ancient practice used to harmonize people with their environment. This course explores an approach to designing with healthy living by integrating planning and design disciplines. To train students' 
design skills and help them improve their living conditions, the professor provides feng-shui lectures, field investigations, evaluation exercises, and consultations.

\section{METHODS}

Teaching and learning systems theory and feng-shui can be challenging. With considering undergraduate student learning behaviors, the course methods include the following components:

[1] Literature studies. Systems philosophy (by Bertalanffy and Laszlo) has provided a philosophical base for this course. Introducing ancient feng-shui text helps students learn the vernacular concepts and contents since ancient people had distinct thinking patterns (Schwartz, 1985). The course reading material also includes journal articles on natural hazards, healthy living, systems theory, and feng-shui to provide a broad range of knowledge for students.

[2] Lectures on precedent designs. Undergraduate students absorb a philosophy well when using examples. The course lectures provide various design precedents, including Beijing city, the royal and intellectual gardens, tombs, and vernacular houses. In each case, there is an emphasis on applying the feng-shui principles and integrating architecture with its surrounding landscape. The ancient Chinese cultural landscape has provided testimonies of the feng-shui practice, a systematic approach to environmental design.

[3] Field investigations. Field lectures and observations can help students understand terms, criteria, and concepts of feng-shui and natural hazards, providing first-hand knowledge to examine theories. Thus, the most effective way to learn feng-shui is to hike for thousands of miles alongside studying literature (Xu, 1580).

[4] Class discussions and student evaluations. In class, students discuss feng-shui criteria after the lectures and field studies. The feng-shui criteria become references for students' feng-shui evaluation of their residences. By utilizing the diagram and matrix, this course helps students establish the systemic concept of the built environment.

[5] Final Presentation and consultations. Students present their living conditions and feng-shui evaluations during the final presentation. The professor provides feng-shui consultants for each student's living conditions, including evaluations and recommendations to resolve the problems.

\section{SYSTEMS PHILOSOPHY AND FENG-SHUI}

Systems philosophy was first conceived by Ludwig von Bertalanffy, an Austrian biologist. During the 1930s and 1940s, he developed the idea of general systems theory. In the 1970s, the Hungarian philosopher Ervin Laszlo's pioneering work developed systems philosophy in breadth and depth (Bertalanffy in Laszlo, 1972). As Von Bertalanffy states, "an interdisciplinary approach to elaborating principles and models applies to systems in general, regardless of their particular kind, elements, and 'forces' involved (Bertalanffy in Laszlo, 1972)."

Systems theory has been broadly applied in natural science, social science, and business, which have become an efficient methodology and developed a new worldview in the contemporary world (Bertalanffy in Laszlo, 1972 and Laszlo, 1996). Systems theory explores "wholes" and "wholeness" to find principles applied in the entire system. Thus, it differs from the conventional analytical method, which divides a system into pieces and examines their details to find the rules for the system. Systems philosophy has roots in ancient thought in the West and the East (Laszlo, 1972).

\section{Feng-Shui: An Ancient Systematic Model}

According to the I Ching (易经), a book of Chinese wisdom written 3000 years ago, ancient Chinese developed the concept of taiji (太极). They believed that the world is a whole, called taiji, representing oneness and duality in the world (Wilhelm and Baynes, 1990). Taiji comprises the yin part, negative and 
dark, and the yang part, positive and light. In yin, there is yang, and in yang, there is yin. Yin and yang form the dynamic universe. In the world, all things are interconnected, integrated, and interdependent. The ancient Chinese sage Lao Zi suggested that pursuing balance in the world should be a goal for life (Wing, 1986). The traditional Chinese belief states that everything is a taiji, a whole, from the universe to the human scale. Taiji represents the Chinese concept of a system.

Feng-shui applies the theories of qi, vital energy, yin and yang, and the five elements, which manifest through the form of the physical world. A favorable feng-shui site should be located where qi accumulates, like an acupuncture point crucial for human health $(\mathrm{Xu}, 1580)$. The vital energy passes through a meandering path while evil travels straight (Ye, 1688). A place with good qi must have adequate sunlight, fresh air, and decent moisture, creating a delightful environment.

Based on the systematic concept and experiences from thousands of years, feng-shui has developed into an art of living in harmony with nature. It derives the benefit, peace, and prosperity from being in the right place at the right time (Skinner, 1982) (Figure 1). With respect for and fear of nature's power, feng-shui also has criteria to control human greed in exploiting natural resources. In feng-shui practice, the environment composes physical and spiritual factors involving geography, geology, ecology, astronomy, climate, environmental psychology, and criminology. The primary goal of feng-shui is to avoid disaster and attract good fortune for safe and healthy living. Thus, as an ancient systematic model for environmental design, feng-shui could be utilized to develop a paradigm of healthy living.

\section{FIGURE 1}

\section{DIAGRAM PRESENTS FENG-SHUI CONCEPT OF LIVING IN HARMONY}

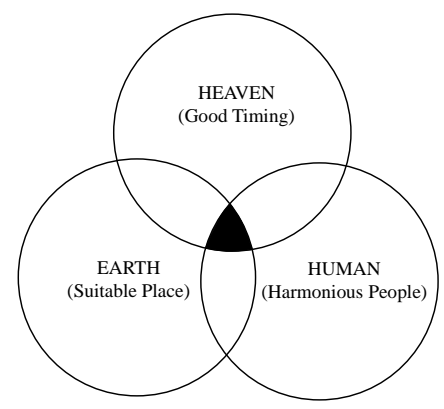

Feng-shui practice encompasses the branches of the yin house feng-shui and the yang house feng-shui. The yin house feng-shui examines landscape surroundings on various scales from mountains, hills, water, site, and orientation for homesites and graveyards (Zhao, 1787). The yang house feng-shui involves the town, city, houses, and interior design (Yao, 1751). At every level, the feng-shui practice emphasizes attracting good qi, vital energy, and averting evil energy. The traditional feng-shui practice encompasses a comprehensive analysis with field investigations of mountains, hills, water, site, and soil, judging orientations with a feng-shui compass, and referencing literature documents (Eitel, 1873).

\section{EVALUATING BUILT ENVIRONMENT FOR HEALTHY LIVING}

Feng-shui is an ancient systematic model for environmental design and can be utilized as a clue to develop a paradigm of healthy living. Inspired by feng-shui, Figure 2 shows the structure of the built environment (Figure 2). This diagram has been drawn on the blackboard in each class and emphasized during the desk critiques. Thus, this diagram helps students establish the systematic concept of the built environment that we live in and design. Combining feng-shui criteria with scientific knowledge, students evaluate their residences from the natural landscape, urban setting, landscape design, architecture, to furniture arrangement. 


\section{FIGURE 2 \\ DIAGRAM SHOWS BUILT ENVIRONMENT STRUCTURE}

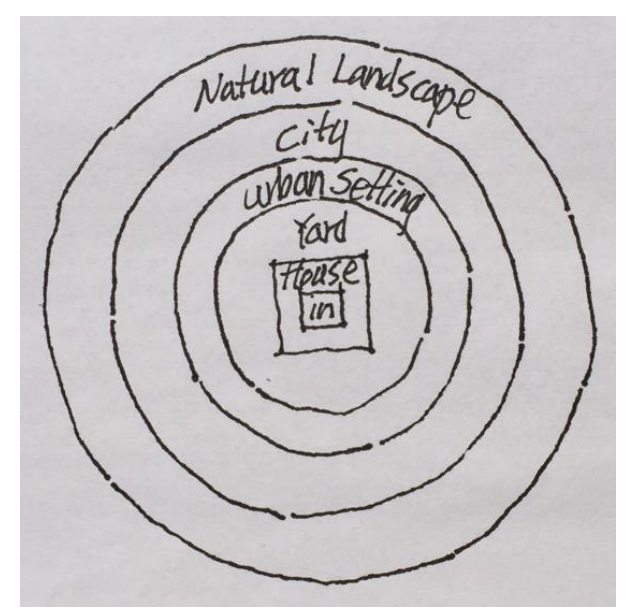

\section{Landscape Analysis With Field Investigations}

By following the diagram of the built environment, students first evaluate natural landscape, including mountains, hills, water, and orientation, because larger-scale considerations are crucial for avoiding future failures (Steinitz, 2012). Introducing a Western landscape analysis method (by Hendler, 1977) provides undergraduate students with a knowledge base to compare with feng-shui. The class field observations have been conducted at Mesa Trail, Boulder, since this area contains a favorable feng-shui site. According to feng-shui, an ideal homesite is in a u-shaped containment enfolded by hills, with a slope to the south, where mountain peaks are in the distance. A meandering river passes through the east or south of the site. In the north, tall hills fence off cold winds. Thus, vital energy accumulates in such a site (Zou, 1676; Zhao, 1787).

According to feng-shui, a home should be on raised land that provides vital energy, fresh air, and proper drainage. A "dragon vein," referring to a hill ridge, could be an ideal choice for a homesite (Yang, 834$900 ; \mathrm{Xu}, 1580)$. Behind a house, the "dragon whiskers," referring to the gullies, can mitigate water away from the site $(\mathrm{Xu}, 1580)$. An individual hill with a strong bedrock foundation is considered a "turtleback" (Yao, 1751). A "turtleback" hill rising over 40 feet higher from its surroundings could provide an excellent drainage system and endure debris flow attacks. Debris flow can go up to 30 feet (King, 2018). Thus, such a "turtleback" hill could provide a place for refuge or evacuation.

Mountainous areas contain the risks of natural hazards. Mountain peaks with steep slopes, feng-shui calls the "fire mountains," could frequently cause fires (Yang, 834-900; Xu, 1580). High land over $8000 \mathrm{ft}$ often triggers lightning strikes, which is a source to ignite wildfires. Forests provide the fuel for wildfires that spread with powerful windstorms. In feng-shui, canyons with steep slopes and narrow channels, full of broken cliffs and rocks, are called the "violent dragon." A mountain peak with a concave basin is called the "sick dragon." Those landforms could bring a deadly disaster (Xu, 1580; Qiu, 1995). A debris flow can originate in the mountains several miles away from its impact area. According to geomorphology research, unstable rocks on slopes often feed debris directly into steep channels, triggering debris flow (Bovis and Jakob, 1999).

To better understand the landscape patterns of areas prone to natural hazards, the class has investigated a high-impact area of the 2013 debris flow, Chapel on the Rock, Allenspark, CO. This debris flow originated from Mt. Meeker five miles away. Mt. Meeker can be classified as a "sick dragon" with a concave basin. This first-hand knowledge enhances students' understanding of larger-scale considerations crucial in site selection to avoid natural hazards. For undergraduate students, the field investigation is an efficient way to learn feng-shui and natural hazards. The students have presented eagerness and curiosity during field observations (Figure 3). 


\section{FIGURE 3 \\ FIELD INVESTIGATION AT AN IMPACT AREA OF 2013 DEBRIS FLOW}

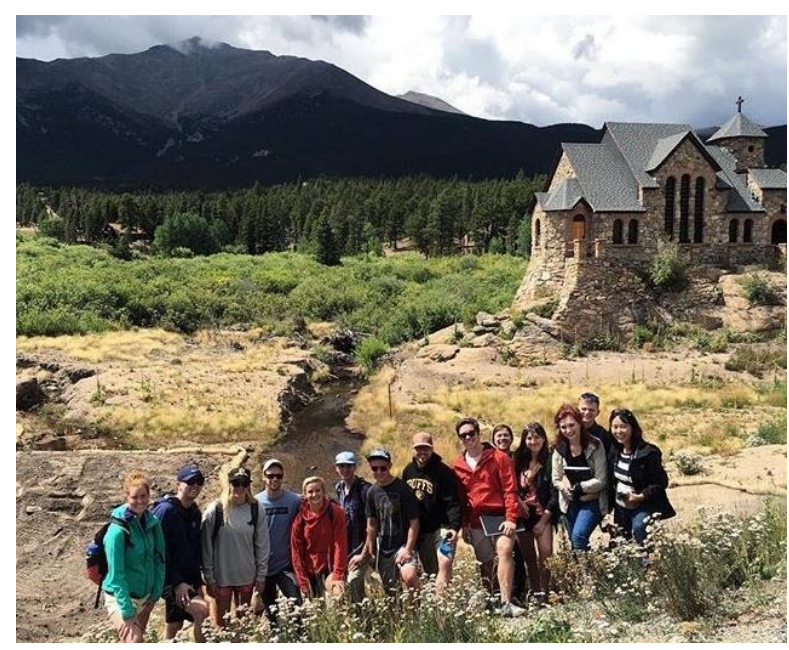

(Source: Hannah Bennett-Haughey)

A narrow canyon with a steep slope or creeks can trigger debris flow (Reneau and Dietrich, 1987). Especially, a dry wash pointing straight towards a house, called "hidden arrow," a debris flow track, could cause vast destruction (Ye, 1688). The field investigations demonstrated that the heaviest impact areas of the 2013 Colorado floods all involved attacks of a "hidden arrow" from debris flow or engulfing flood. The confluence area could have high flood impacts, particularly on outside a curve flow (Ye, 1688; Yao, 1751). A site with even level grading could prompt flooding (Zhou, 1368-1644).

The primary concerns of site selection are avoiding the areas prone to mountain floods and debris flow and selecting the sites having proper terrains to sustain. However, the spatial distribution of a natural hazard, such as debris flow, is not well researched (Lorente, et al., 2002). The field investigations indicate that the high-impact areas correspond to the negative feng-shui criteria while the surviving areas correspond to the favorable criteria. Thus, feng-shui can provide a clue to identify landscape patterns of areas susceptible to debris flow, emphasizing spatial characteristics and relationships amongst landscape elements (Xu, 2016).

\section{Hazard Impacts on Human Health}

Homes located in areas prone to natural hazards could result in injury, illness, and even fatalities. Avoiding cold winds is a primary strategy of feng-shui practice $(\mathrm{Xu}, 1580)$. Research evidence indicates that windstorm impacts on health include infections and insect bites (Goldenman, et al., 2014). Some seniors have claimed experiences of facial paralysis or loss of vision for an entire month after yard work during a windstorm. Floods and debris flow could destroy properties and cause fatalities. Floods can damage the infrastructure and drainage system, which could pollute the surface and groundwater. Flooded buildings can lead to the growth of mold and mildew. Research has indicated an increased risk of disease outbreaks in a post-flood period, such as hepatitis E, gastrointestinal disease, and leptospirosis (Alderman, et al., 2012).

Moreover, wildfires can cause substantial impacts on human health. Burned trees release large amounts of carbon dioxide and can no longer filter pollutants or produce oxygen. Inhalation of smoke and ash from large wildfires creates serious health threats for the elderly, ill, and those with heart or respiratory conditions (Balmes, et al., 2016). Extended recovery periods on burned slopes leave them vulnerable to debris flow disasters. By analyzing fire impacts on human health and consequences on ecological balance, fires nearby residences should be extinguished immediately $(\mathrm{Xu}, 2017)$. 


\section{Evaluating Urban Settings}

After analyzing the large-scale landscape, students evaluate living conditions relevant to the urban settings and provide plans and photos of their urban surroundings. Combining feng-shui and scientific knowledge inspires new criteria for healthy living in the contemporary built environment. According to feng-shui, house design significantly impacts resident health and fate (Wang, 1882). The house design practice called the yang house feng-shui focuses on designing for living people, containing two sections of the "external issues" and the "inner issues." The "external issues" correspond to the contemporary urban and landscape design practice, and the "inner issues" align with architecture and interior design. The fengshui criteria provide references for students' evaluations.

Feng-shui recommends a homesite on the south, southeast, or east slope, to receive adequate sunlight and avoid cold winds. At the front of a house, an open space with gentle slopes should have no tall obstructions of hills or buildings blocking sunlight and fresh air. A house should sit on a spot higher than the surroundings to avoid flooding (Yao, 1751). Underground water passing through a house could cause sickness and trepidation ( $\mathrm{Li}, 1993)$. Research indicates that a house located on a wet and low land could cause rheumatic diseases (Palaty and Shum, 2012). Damp housing conditions increase severe respiratory illness, in which children have higher odds than adults of contracting (Ige, et al., 2018).

According to feng-shui, a road or a bridge pointing directly towards a house would trigger negative energy for the inhabitants (Wang, 1882). A house located outside a curved road is also unfavorable, increasing the risk of driving into the house (Figure 4). Research indicates road noise entering through bedroom windows could increase cardiovascular and hypertension risk (Cedeno-Laurent, et al., 2018). In addition, residing nearby a transmission tower would cause harm to residents. The author's investigations indicate that several seniors who live near a high voltage transmission tower have consequently died from cancer. Thus, houses located on such a site could cause a challenging resale.

\section{FIGURE 4 \\ A VEHICLE DROVE INTO THE HOUSE LOCATED OUTSIDE A CURVED ROAD AROUND MIDNIGHT}

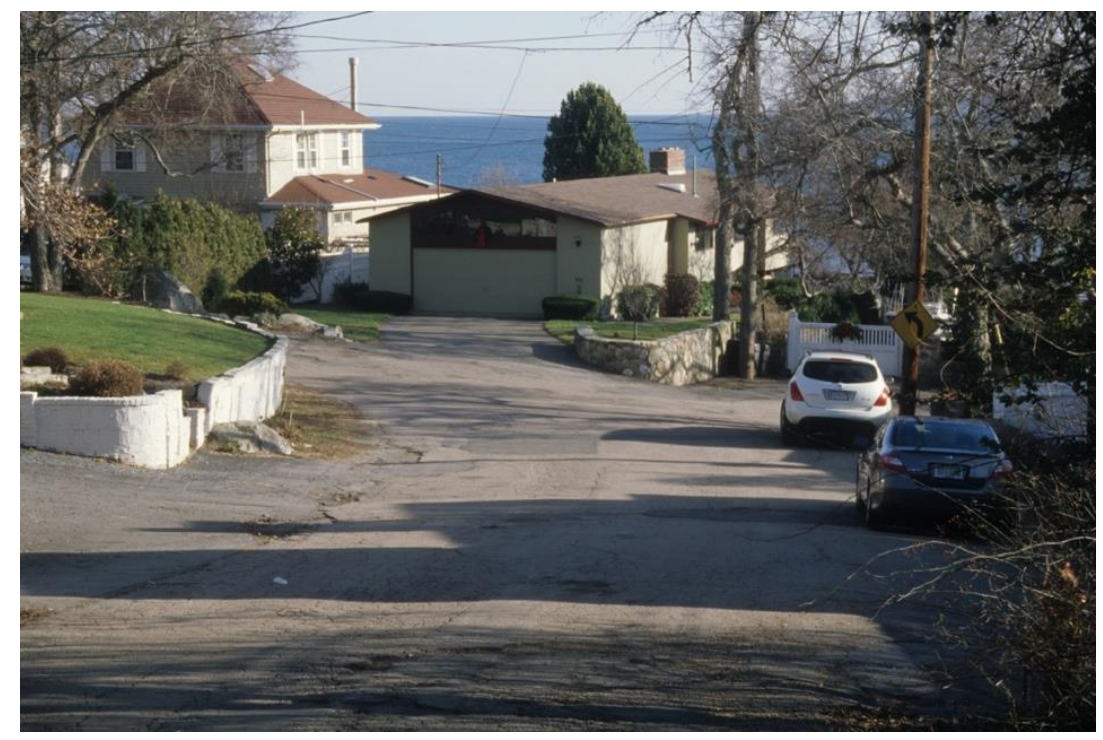

\section{Evaluating Landscape Design}

Landscape design can also impact healthy living. Feng-shui recommends the house gate be in favorable positions -- the east, south, or southeast of a residence. Rocks are placed at the entrance, the end of a road or path, or by lakes to ward off evil spirits. However, removing rocks from a temple or graveyard to a home may cause a bad fortune. In addition, people should select proper trees to plant on a home site (Wang, 
1882). Research demonstrates that people living in the forest have lower heart rates, and the fresh air promotes lung health (Park, et al., 2010). On the other hand, some trees can cause pollen allergies during the spring (Schmidt, 2016). Feng-shui also warns people that a pool located in the front of a house could lead to the loss of a child, and a pool located on the west could cause eye disease (Wang, 1882). Extended exposure to water reflection could cause eye cataracts, which people living by an ocean have experienced. Scientific studies indicate that uncomfortable glare, direct light, high illumination, and high-contrast conditions can cause visual illness, including strain, irritation, and blurred vision (Cedeno-Laurent, et al., 2018).

\section{Evaluating House Design for Healthy Living}

After analyzing the "external issues" of urban surroundings, students evaluate the feng-shui quality on the "inner issues" of house design, providing plans, sections, and photographs of their residences. Studies from public health literature on hazards in residences identified that the primary health risks are hygrothermal conditions, radon, falls, dust mites, tobacco smoke, and fires (Northridge, 2003). Furthermore, it is imperative to research the spatial factors of houses' orientation, position, and form and their impacts on human health and well-being.

\section{House Form and Plan Layout}

The house form could impact the residents' health. A house with "a room inside another room" could be prone to severe illness, even death (Wang, 1882). Living with poor air circulation and radon accumulation, several senior homeowners living in a house with such a form, have been diagnosed with cancer. A triangular form in plan and section could make occupants confused, anxious, and stressed. During the Denver Art Museum opening ceremony, a senior lady fell, which could be caused by dizziness from experiencing a series of triangular spaces. Studies suggest that the brain harbors visual sensitivities to psychological dimensions of coherence, fascination, hominess, and comfort in architectural interior space (Coburn, et al., 2020).

Feng-shui suggests exterior doors and windows face southeast, south, and east, but not northeast. A mirror on the wall opposite to an entrance could deter evil energy from entering the house. The entrance should not align with the exit or a window to prevent vital energy from dispersion. (Yao, 1751). On the other hand, adequate ventilation is crucial. People working in a confined office without windows can frequently catch the flu. Thus, keeping windows open is an important strategy to mitigate virus propagation during the pandemic. Moreover, keeping a house clean and hygienic is crucial. Research indicates that dust is storage for various harmful agents, including viruses, bacteria, chemicals, allergens, dander, fabric fibers, and paint flakes with lead (Cedeno-Laurent, et al., 2018).

Undergraduate students learn feng-shui principles well through examples. Traditional Chinese courtyard houses provide an excellent example to learn feng-shui. Beijing courtyard houses take symmetric forms. A small entrance and meandering path throughout the house would help maintain vital energy and prevent potential attacks. On the other hand, the house has large windows opened to the central yard, with adequate ventilation and sunlight. To maintain privacy and prevent potential criminal attacks, the exterior walls of traditional courtyard houses have no windows (Xu, 1998).

The sharp edges of walls could injure people's shoulders, which is often an experience of undergraduate students who move fast. Thus, the edges of the walls should be curved. Some paints on walls, floors, or furniture may contain VOCs (volatile organic compounds). VOCs can cause breathing difficulty, nausea, and damage to the central nervous system and other organs, even causing cancer (Dai, et al., 2017). A water leak or flood in a house can cause mold and mildew on walls and floors, as both can cause health problems with prolonged exposure. Scientific research demonstrates that over one-fifth of asthma is attributable to residential dampness and mold (Cedeno-Laurent, et al., 2018).

Feng-shui states the position of an oven could determine the inhabitants' health and good fortune (Wang, 1882). Scientific research demonstrates that cooking fumes containing carcinogenic compounds could increase the risk of respiratory cancer (Svedahl, et al., 2009). Therefore, the kitchen should have 
adequate ventilation. The bedroom doors should be closed to prevent the cooking fumes from entering bedrooms during cooking.

\section{Section Design}

According to feng-shui, a perpendicular beam above a bed could provoke headaches and illness (Rossbach, 1991) (Figure 5a). A bed at the lower point of a sloped roof would make the resident stressed, which is often experienced by college students who live in such a condition because of cheap rent (Figure 5b.) A skylight inviting light into a house would be delightful; however, placement above a bed can increase stress from insecurity (Figure 5c). A high ceiling over 12 feet in a bedroom could cause sleep difficulty, while a ceiling lower than 8 feet may provoke nightmares.

\section{FIGURE 5}

\section{UNFAVORABLE FENG-SHUI CASES}

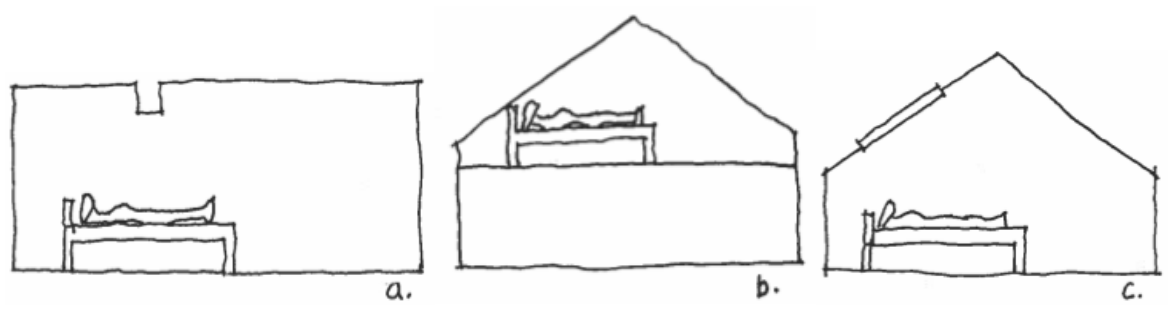

Stairs are critical elements that can cause many health issues. A beam placed too low above a stair can cause a head injury, which is often the case with student rentals. The landlord can place a soft material to cover the beam, which may avoid a lawsuit, but this does not reduce the stress caused daily for student tenants. Entrances of a stair and a bedroom should not be parallel since mistakenly entering a stairwell as a bedroom can cause a falling accident. With split levels, one step built in any place can increase the risk of injury. Conflicting information from adjacent design elements can heighten stress (Evans and McCoy, 1998).

People should avoid inhabiting a basement as a living place since heavily polluted air and radon often deposit in basements. Unfortunately, some students live in basements because of affordable rent. Scientific research demonstrates that radon is a radioactive gas occurring from uranium decay. Radon can enter homes and be inhaled by residents. Residential radon significantly contributes to lung cancer among the residents (Ou, et al., 2018). Exercising in a fitness area of the basement could make people inhale high amounts of radon. If inhabiting a basement, adequate ventilation is necessary by frequently opening windows and using a fan.

\section{Furniture Arrangement}

The orientation and position of a bed can highly impact mental and physical health. Bed placement should avoid direct vision from the door to maintain privacy (Figure 6a). A mirror is placed to provide a reflective view of the entry door (Rossbach, 1991). Students often place their beds against a window for fresh air, and they experience reoccurring headaches (Figure 6b). A bed right next to a large window could increase the risk of flu and other illnesses (Figure 6c). A student claimed to experience bad dreams consistently; it turns out a hole/pit in the floor was under the bed, possibly causing radon to enter the room. When working at a desk, the human back should not face toward a door to remain secure, nor face toward a window to avoid illness. Also, for safety, people should not place the desk directly towards a window facing the street. The contemporary feng-shui practice recommends hanging crystal balls over the entrance to attract good luck. However, objects placed above the head can cause stress. 
FIGURE 6

INAPPROPRIATE BED ARRANGEMENTS
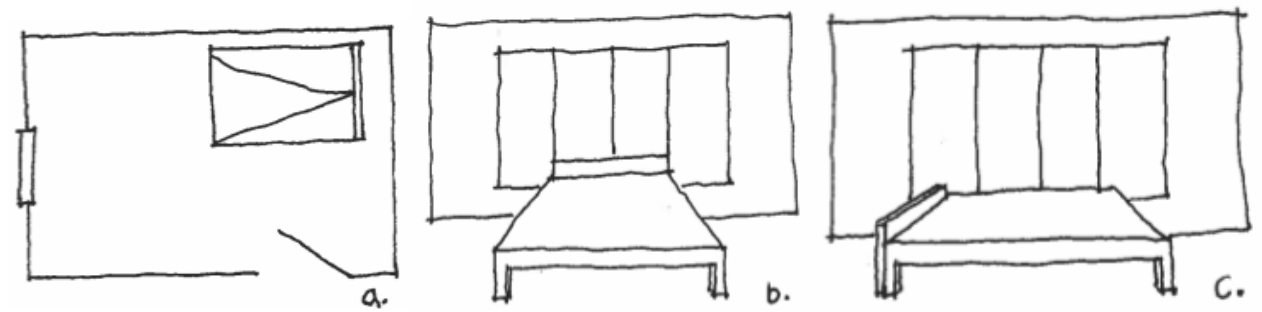

\section{PRESENTATION, DISCUSSIONS, AND CONSULTATION}

During the final presentation, students present the work evaluating their residences with a completed matrix. The professor designs this matrix table for students to evaluate their residences' feng-shui and healthy living qualities (Table 1). The left two columns of this matrix correspond the feng-shui structure to the contemporary practice of environmental design. Using feng-shui criteria as references, students evaluate their living environment with the matrix, from natural surroundings, urban setting, garden, architecture to furniture arrangement, comparing feng-shui criteria with scientific knowledge to gain insight into the essential feng-shui concepts.

In class discussions, students bring out significant issues relevant to healthy living. The professor provides feng-shui evaluations and recommendations for each student's living conditions. By sharing students' experiences, the class discussion enhances understanding of feng-shui and inspires new design ideas of healthy living. Students show great interest and enthusiasm during the entire class in learning this synthesized design approach. Finally, students sum up that feng-shui is an ancient systematic approach to environmental design rather than mythology. They have been eager to apply the integrative concepts in their future designs.

TABLE 1

\section{A MATRIX TO EVALUATE FENG-SHUI QUALITIES AND HEALTHY LIVING OF RESIDENCES}

\begin{tabular}{|c|c|c|c|c|c|c|c|}
\hline \multirow[t]{2}{*}{$\begin{array}{l}\text { Environmental } \\
\text { Design }\end{array}$} & \multirow{2}{*}{$\begin{array}{l}\text { Feng-shui } \\
\text { Criteria for } \\
\text { Healthy } \\
\text { Living }\end{array}$} & \multirow{2}{*}{$\begin{array}{l}\text { Scientific } \\
\text { Study } \\
\text { Support } \\
\text { Yes }\end{array}$} & \multicolumn{5}{|c|}{$\begin{array}{l}\text { Student's Residence } \\
\text { location: }\end{array}$} \\
\hline & & & No & Positive & Negative & $\begin{array}{l}\text { Experience } \\
\text { in Healthy } \\
\text { living }\end{array}$ & $\begin{array}{l}\text { How to } \\
\text { Improve }\end{array}$ \\
\hline \multirow{5}{*}{$\begin{array}{l}\text { Natural } \\
\text { Landscape }\end{array}$} & Mountains & & & & & & \\
\hline & Hills & & & & & & \\
\hline & Water & & & & & & \\
\hline & Site \& Views & & & & & & \\
\hline & Orientation & & & & & & \\
\hline \multirow{6}{*}{ Urban Design } & Neighborhood & & & & & & \\
\hline & $\begin{array}{l}\text { Road \& } \\
\text { Bridge }\end{array}$ & & & & & & \\
\hline & Trees & & & & & & \\
\hline & Pool & & & & & & \\
\hline & Rocks & & & & & & \\
\hline & Gate & & & & & & \\
\hline
\end{tabular}




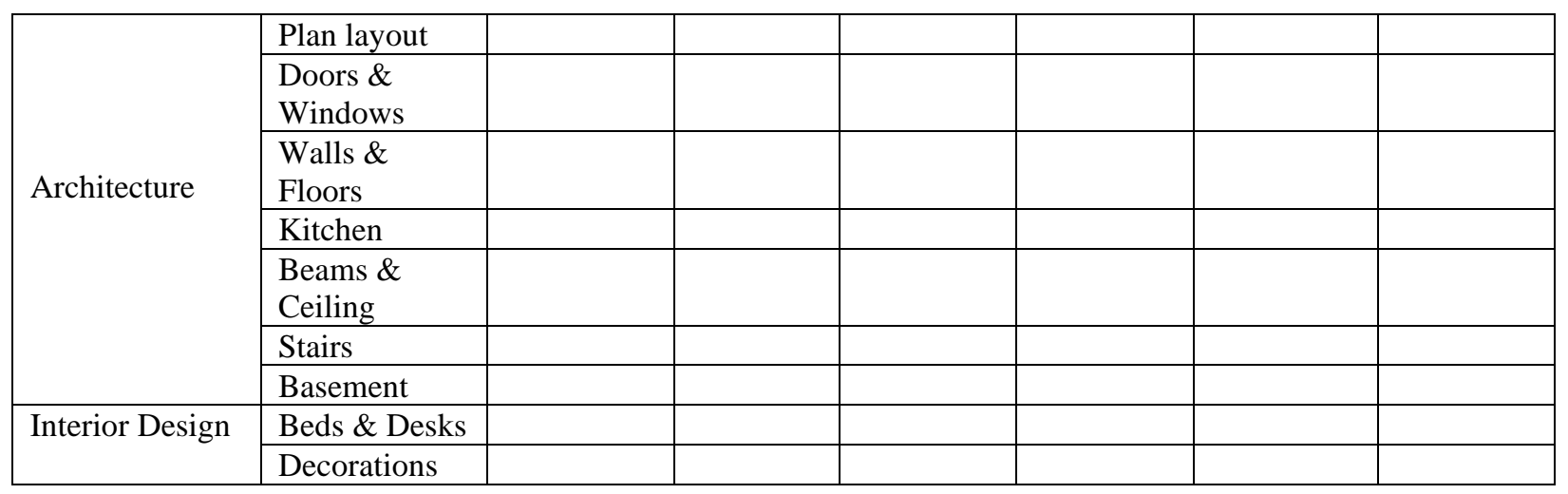

\section{CONCLUSION}

Systems theory explores "wholeness" to find principles applied in the entire system. It differs from the conventional analytical method dividing a system into pieces and examining the details (Lazlo, 1972). It is not surprising that some architectural specialists shaped by conventional education find applying systems theory difficult. In contrast, undergraduate students have presented interests in learning systems philosophy. They have received systems theory well and used it after learning. Therefore, as a general philosophy, systems theory can be feasible and beneficial in undergraduate education.

By combining the feng-shui practice and scientific knowledge studied, this undergraduate course explores an approach to designing houses with healthy living as its primary focus. Homes located in areas prone to natural hazards could result in injury, illness, and even fatalities. It is essential to design a house with abundant sunlight and decent ventilation to prevent the spread and growth of viruses, bacteria, mildew, radon, and pollutants. Furthermore, the spatial aspects of orientation, position, and forms are imperative for enhancing healthy living.

Enhancing healthy living in the built environment should be a primary goal for designers. However, the concepts and knowledge of healthy living rarely appear in curriculums. To improve this weakness in architectural education, the author suggests introducing systems philosophy and the knowledge of natural hazards and healthy living into curriculums. In addition, increasing field investigations would benefit teaching theory courses because students can use the first-hand experience while examining a theory. Many undergraduate students love field trips; most are energetic hikers, nature lovers, and quick learners through keen observation.

The differences between the feng-shui practice and contemporary architectural professionals are that feng-shui deals with the environment as a whole system. Feng-shui incorporates house design with comprehensive analysis from mountains and water, urban surroundings, landscape design, architecture to furniture arrangement. Inspired by feng-shui, this course explores a synthesized approach to healthy living, integrating planning and design disciplines. Insight into feng-shui practice with the comparison of scientific knowledge helps students understand the vernacular method's values for healthy living. Ultimately, this course enhances undergraduate students' understanding of systems theory, a fundamental worldview in the contemporary world.

\section{ACKNOWLEDGMENTS}

The author would like to thank Keaton McCargo and Alyssa Drain for helping edit this paper. 


\section{REFERENCES}

Alderman, K., Turner, L.R., \& Tong, S. (2012). Floods and human health: A systematic review. Environment International, 47, 37-47. https://doi.org/10.1016/j.envint.2012.06.003

Balmes, R.J., Brauer, M., Elliot, T.C., Jerrett, M., Johnston, H.F., \& Reid, E.C. (2016). Critical review of health impacts of wildfire smoke exposure. Environmental Health Perspectives, 124(9), 13341343. https://doi.org/10.1289/ehp.1409277

Bovis, M., \& Jakob, M. (1999). The role of debris supply conditions in predicting debris flow activity. Earth Surface Processes and Landforms, 24, 1039-1054.

Cedeño-Laurent, J., Williams, A., MacNaughton, P., Cao, X., Eitland, E., Spengler, J., \& Allen, J. (2018). Building evidence for health: Green buildings, current science, and future challenges. Annual Review of Public Health, 39(1), 291-308. https://doi.org/10.1146/annurev-publhealth-031816044420

Chen, B. 陳寶森. (1995). Chengde bishu shanzhuang Waibamiao 承德避暑山莊 外八廟 [Chengde summer palaces and eight outer temples]. Beijing: Zhongguo jianzhu gongji chubanshe.

Coburn, A., Vartanian, O., Kenett, Y.N., Nadal, M., Hartung, F., Hayn-Leichsenring, G., . . Chatterjee, A. (2020). Psychological and neural responses to architectural interiors. Cortex, 126, 217-241. https://doi.org/10.1016/j.cortex.2020.01.009

Costa, J.E., \& Wieczorek, G.F. (1987). Debris flow/avalanches: Process, recognition, and mitigation. Boulder: The Geological Society of America.

Dai, H., Jing, S., Wang, H., Ma, Y., Li, L., Song, W., \& Kan, H. (2017). VOC characteristics and inhalation health risks in newly renovated residences in Shanghai, China. The Science of the Total Environment, 577, 73-83. https://doi.org/10.1016/j.scitotenv.2016.10.071

Eitel, E.J. (1873). Feng-shui: The Science of Sacred Landscape in Old China. London: Trubner \& Co.

Eitel, E.J. (1985). Feng-shui: The Science of Sacred Landscape in Old China, with commentary by John Michell. London: Synergetic Press.

Evans, G.W. (2003). The built environment and mental health. Journal of Urban Health: Bulletin of the New York Academy of Medicine, 80(4), 536-555. https://doi.org/10.1093/jurban/jtg063

Evans, G.W., \& McCoy, J.M. (1998). When buildings don't work: The role of architecture in human health. Journal of Environmental Psychology, 18(1), 85-94. https://doi.org/10.1006/jevp.1998.0089

Goldman, A., Eggen, B., Golding, B., \& Murray, V. (2014). The health impacts of windstorms: A systematic literature review. Public Health, 128(1), 3-28. https://doi.org/10.1016/j.puhe.2013.09.022

Guo, P. 郭璞. (276-324). Zang ji 葬經 [Burial book] Collected in Dili tianji huiyuan by Xu Shike, 1580. Shanghai: Shanghai jiaojing shanfang.

Hendler, B. (1977). Caring for the Land: Environmental Principles for Site Design and Review. Chicago: American Society of Planning Officials.

Ige, J., Pilkington, P., Orme, J., Williams, B., Prestwood, E., Black, D., . . Scally, G. (2018). The relationship between buildings and health: a systematic review. Journal of Public Health, 41(2), 121-131. https://doi.org/10.1093/pubmed/fdy138

Jiang, W. 姜威国. (1997). Xiandai fengshuixue luantou zonglun 現代風水學變頭總論 [Modern fengshui landform theory]. Taipei: Yiqun shudian.

King, H.M. (2018). What is a debris flow? Geoscience News and Information. Retrieved from https://geology.com/articles/debris-flow/

Laszlo, E. (1972). Introduction to Systems Philosophy, with a foreword by Ludwig von Bertalanffy. London: Gordon and Breach Science Publishers.

Li, R. 李人奎. (1993). Feng-shui cilin mijie 風水辭林秘解 [Decoding secrets of feng-shui vocabulary]. Taibei: Quanyuan chubanshe. 
Liu, J. 劉基. (1986). Zhencang guben kanyu miji qishu珍藏古本堪與秘篖奇書 [Collection of ancient texts (reprinting 50 historical famous masterworks from 200 BC to 1600 AD)]. Taibei: Fuli chuban youxian gongsi.

Lorente, A., García-Ruiz, J.M., Beguería, S., \& Arnáez, J. (2002). Factors explaining the spatial distribution of hillslope debris flows: A case study in the Flysch sector of the central Spanish Pyrenees. Mountain Research and Development, 22(1), 32-29.

McHarg, I. (1971). Design with Nature. New York: Doubleday.

McHarg, I. (1996). A Quest for Life. New York: John Wiley \& Sons, Inc.

Northridge, M.E. (2003). Sorting out the connections between the built environment and health: A conceptual framework for navigating pathways and planning healthy cities. Journal of Urban Health: Bulletin of the New York Academy of Medicine, 80(4), 556-568. https://doi.org/10.1093/jurban/jtg064

Ou, J.Y., Fowler, B., Ding, Q., Kirchhoff, A.C., Pappas, L., Boucher, K., . . Kepka, D. (2018). A statewide investigation of geographic lung cancer incidence patterns and radon exposure in a low-smoking population. BMC Cancer, 18(1), 1-8. https://doi.org/10.1186/s12885-018-4002-9

Palaty, C., \& Shum, M. (2012). Health effects from mould exposure or dampness in indoor environments. National Collaborating Centre for Environmental Health, pp. 1-7.

Park, B.J., Tsunetsugu, Y., Kasetani, T., Kagawa, T., \& Miyazaki, Y. (2010). The physiological effects of Shinrin-yoku (taking in the forest atmosphere or forest bathing): Evidence from field experiments in 24 forests across Japan. Environmental Health and Preventive Medicine, 15(1), 18-26. https://doi.org/10.1007/s12199-009-0086-9

Qiu, Y. 邱于展. (1995). Dili luantou jiyao 地理巒頭辑要 [Geographic landform guides].Taibei: Xinfeng wenhua shiye gongsi.

Reneau, S.L., \& Dietrich, W.E. (1987). The importance of hollows in debris flow studies: Examples from Marin County, California. In J.E. Costa \& G.F. Wieczorek (Eds.), Debris flow/avalanches: Process, recognition and mitigation (pp. 165-179). Boulder: The Geological Society of America.

Rice, L., \& Drane, M. (2020). Indicators of healthy architecture - a systematic literature review. Journal of Urban Health, 97(6), 899-911. https://doi.org/10.1007/s11524-020-00469-z

Rossbach, S. (1991). Interior Design with Feng-shui. London: Arkana.

Schmidt, C.W. (2016). Pollen overload: Seasonal allergies in a changing climate. Environmental Health Perspectives, 124(4), 70-75. https://doi.org/10.1289/ehp.124-A70

Schwartz, B.I. (1985). The World of Thought in Ancient China. Cambridge: Belknap Press of Harvard University Press.

Skinner, S. (1982). The Living Earth Manual of Feng-shui: Chinese Geomancy. London: Routledge \& Kegan Paul.

Steinitz, C. (2012). A Framework for Geodesign: Changing Geography by Design. Redlands: Esri.

Svedahl, S., Svendsen, K., Qvenild, T., Sjaastad, A., \& Hilt, B. (2009). Short term exposure to cooking fumes and pulmonary function. Journal of Occupational Medicine and Toxicology, 4(1), 9. https://doi.org/10.1186/1745-6673-4-9

von Bertalanffy, L.V. (1968). General System Theory. New York: George Braziller, Inc.

Wang, J. 王君榮. (1882). Yangzhai shi shu 陽宅十書 [Ten writings on yang house feng-shui]. Shanghai:

Caoye shanfang.

Wilhelm, H., \& Baynes, C. (1990). The I Ching, or Book of Changes, translated by Wilhelm and Baynes. $24^{\text {th }}$ printing. Princeton: Princeton University Press.

Wing, R.L. (1986). The Tao of Power, A Translation of Tao Te Ching by Lao Yzu. New York: Doubleday.

Xu, P. (1991). Feng-shui: A model for landscape analysis. Council of Educators in Landscape Architecture (CELA 90) Proceedings, pp. 183-193.

Xu, P. (1998). Feng-shui models structure traditional Beijing courtyard houses. Journal of Architectural and Planning Research, 15(4), 271-282. 
Xu, P. (2016). Feng-shui - Ancient geodesign as a clue: Identifying predictive landform models of mountain flood impact zones. Journal of Digital Landscape Architecture, 1, 141-148.

$\mathrm{Xu}, \mathrm{P}$. (2017). Fires and postfire debris flows triggered by landforms in Colorado Front Range and the subsequent impact on and by humans. Journal of Digital Landscape Architecture, 2, 63-74.

$\mathrm{Xu}, \mathrm{S}$. 徐试可. (1580). Dili tianji huiyuan 地理天機會元 [Compilation of geography secrets]. Shanghai: Shanghai jiaojing shanfang.

Yang, J. 楊等松. (834-900). Qingnang aoyu 青囊奧語, Han long jing 撼龍經, Yi long jing 疑龍經 (collected in Dili tianji huiyuan by Xu Shike, 1580, Shanghai: Shanghai jiaojing shanfang).

Yao, T. 姚廷鑾. (1751). Yin yang er zhai quan shu陰陽二宅全書 [The feng-shui book of the yin house and the yang house]. Shanghai: Shanghai da cheng shuju.

Ye, J. 葉九升. (1688). Dili da cheng 地理大成 [Geography compilation]. Shanghai: Shanghai jiu jing shuju.

Zhang, S. 張述任, \& Zhang Yihe 張怡鶴. (2009). Huangdi zhaijing -feng-shui xinde 黃帝宅經 - 風水 心得 [Reprint with explanation and insight into ancient text of house book]. Beijing: Tuanjie chubanshe.

Zhao, J. 趙九峰. (1787). Huitu dili wujue 繪圖地理五訣 [Five categories of geography (mountains, hills, water, site, and orientation) with illustrations]. Shanghai: Shanghai huiwen shutang.

Zhou, S. 周视. (1368-1644). Yinyang dinlun陰陽定論 [Yin yang theory]. Collected in Liu Ji 刘基, 1986. 珍藏古本堪與秘笈奇书 [Collection of ancient texts (reprinting 50 historical famous masterworks from $200 \mathrm{BC}$ to $1600 \mathrm{AD}$ )]. Taibei: Fuli chuban youxian gongsi. Volume 2.

Zou, T. 㮲廷猷. (1676). Zengtu dili daquan ershisan juan 增圖地理大全二十三卷 [Compilation of geography books with twenty-three volumes and illustrations]. Shanghai: Shanghai jiaojing shanfang. 